\title{
Hotels' marketing mix responses at insecurity-stricken destinations: a study in the US-Mexico border
}

\author{
Oliver Cruz-Milán \\ Department of Management and Marketing, Texas A\&M University-Corpus Christi, \\ Corpus Christi, Texas, USA
}

\begin{abstract}
Purpose - The purpose of this paper is to investigate specific marketing mix activities and influencing factors in hotels coping with falling room demand derived from drug cartel-related risk and insecurity.

Design/methodology/approach - A case study research was carried out using semistructured interviews with key informants (hotel managers) in two neighboring destinations at the US-Mexico border, an area where criminal organizations' drug trafficking-related violence has impacted the hospitality industry.

Findings - The research identifies factors that are internal (market segment diversification, type of ownership, magnitude of investments) and external (tourism promotion organizations, media coverage, tourist flow volume) to the firms as they affect their marketing mix implementation.

Research limitations/implications - The research developed a framework to better understand the use of marketing mix practices and influencing factors in criminal insecurity contexts, which could be further studied in other risk and conflict scenarios.

Practical implications - The pricing and communication tactics are employed more intensively, while product-service and distribution channel actions are used to a lesser extent. Greater emphasis should be placed on product-service, distribution and market segment diversification.

Social implications - Considering the positive impacts that tourism and hospitality businesses have on local communities, it is recommended that the hotel sector works together with government and industry associations to improve the safety and security at tourism destinations.

Originality/value - The research extends the extant knowledge in hospitality crisis management by investigating the full marketing mix tactics in hotels at destinations stricken by cartel-related organized crime, an understudied context in the literature.
\end{abstract}

Keywords Crime-ridden destinations, Drug cartels, Hotel marketing mix, Tourism crisis, Tourist risk,

US-Mexico border

Paper type Research paper

\section{Introduction}

Risk and insecurity crises are a growing issue worldwide (Pennington-Gray, 2018) and are among the major problems that can severely affect the competitiveness and performance of tourism destinations (Assaf and Josiassen, 2012), given that tourists' decisions and behavior are strongly influenced by the perceptions of safety in host countries or regions (Caber et al., 2020; Pizam and Mansfeld, 2006). Security-related issues have long been of interest in the tourism and hospitality literature (Jiang et al., 2019), encompassing research from the perspective of destination crisis planning and management (Blackman and Ritchie, 2007; Pennington-Gray et al., 2011), travelers' attitudes and behavior (Karl et al., 2020; Kozak et al., 2007), and responses by hospitality businesses and firms to various types of security threats (Dahles and Susilowati, 2015; Israeli et al., 2011; Wang and Ritchie, 2010), including those

(C) Oliver Cruz-Milán. Published in International Hospitality Review. Published by Emerald Publishing Limited. This article is published under the Creative Commons Attribution (CC BY 4.0) licence. Anyone may reproduce, distribute, translate and create derivative works of this article (for both commercial and non-commercial purposes), subject to full attribution to the original publication and authors. The full terms of this licence may be seen at http://creativecommons.org/licences/by/4.0/legalcode

Received 18 September 2020 Revised 13 November 2020 22 December 2020

Accepted 22 December 2020

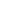


IHR

36,1

132

related to criminal activity. Among the latter, extant studies have largely focused on measures taken by businesses in insecurity contexts, with particular focus on the adoption or enhancement of product-related features. However, research on the responses of hospitality businesses with respect to other marketing mix activities (e.g. distribution, pricing, and promotion) has been neglected.

The marketing mix, referred traditionally as the marketer's "tool kit," comprises the set of crucial instruments to carry out and materialize marketing strategies (Marshall and Johnston, 2019). According to Vorhies and Morgan (2005), marketing mix activities constitute firm capabilities through which businesses transform available resources into valuable outputs, enabling them to deliver superior financial performance and enhance competitive advantages (Hunt, 2010). The importance of the joint and overall effects of marketing-mix variables on companies' revenues and value growth has been empirically demonstrated in consumer goods industries (e.g. Blut et al., 2018; Datta et al., 2017; Kumar et al., 2009). Under these same principles, marketing mix decisions in service firms are pivotal to build customer relationships and attain business objectives, which are usually derived from a previous process of strategic planning (Tsiotsou and Goldsmith, 2012). However, little is known in the literature about the factors and conditions that determine the implementation of such marketing mix tactics when sudden, unexpected crisis situations arise and the crisis signals are not detected in a timely manner as to formulate strategic plans, and thus a reactive approach is typically followed by unprepared hospitality managers (Johnson Tew et al., 2008; Paraskevas and Altinay, 2013). According to the research carried out by Alonso-Almeida et al. (2015), marketing-based capabilities deployed through the marketing mix are key drivers to maintain or improve market position and survive during times of crisis in the hospitality sector. Therefore, considering the crucial role of marketing mix strategies for achieving the desired business outcomes in the hospitality industry (Kotler et al., 2016; Lewis and Chambers, 2000; Stutts and Wortman, 2006), and the recent call for research to explore a wider range of marketing mix activities in risk crisis settings (Masa'deh et al., 2018; Salman et al., 2017), the objective of this study is to investigate the marketing mix implementation and influencing factors in hotels at criminality- and in insecurity-stricken destinations.

Against this backdrop, and given the scarcity of research on this topic and the exploratory nature of the study, two fundamental questions guide this work. The first research question is: What are the marketing mix tactics commonly implemented by hotels in the context of risk and insecurity in a tourism region? Identifying the marketing mix activities employed by hotels represents a first, necessary step to further elaborate an answer to respond the second research question: What factors influence the implementation of such marketing mix tactics by the firms? According to Kotler and Keller (2016), a company's marketing mix decisions may depend on various generic factors (e.g. business model and goals, competition, the product life cycle, etc.). However, in the case of hospitality businesses, a more detailed understanding of the specific marketing mix used and the factors that influence such decisions, with the added complexity of operating in crime and insecurity-related contexts (see Tarlow, 2014), has been absent in the travel and tourism crisis literature.

The research idea emerged initially from the author's personal experience living in a region where the tourism industry became dramatically impacted in the midst of a crime and violence-related crisis, witnessing the struggles and hardships faced suddenly by hospitality businesses and realizing the lack of works in the published literature about specific marketing tactics employed in such situations. According to Kock et al. (2020), this type of phenomenon-based study in which research questions are originally "gathered from life" (p. 1141), allows to capture, describe and document a phenomenon of interest that can be further investigated empirically. This is in line with the inductive approach to research unique, varying types and contexts of crises understudied in the tourism industry, as noted by Pennington-Gray (2018). In this way, this inquiry adds to the extant body of knowledge by 
extending research on hospitality marketing management in risk and insecurity crises into the context of destinations affected by transnational organized crime, a setting not studied before in the literature, which constitutes a relevant type of academic contribution (Ladik and Stewart, 2008; Whetten, 1989).

As a way to address the research questions, this investigation follows a case study approach as recommended for exploratory research, in line with previous studies in the tourism literature (see Xiao, 2010). First, a review of the literature identifies the gap in the extant body of research by pointing out the scarcity of studies related to the use of all the marketing mix elements in hospitality firms at destinations during insecurity crises. Then, the study method and context are described, followed by the analysis and discussion of research results. Finally, theoretical and managerial implications, limitations and avenues for further research are presented.

\section{Literature and background}

\section{Crises, risk, and insecurity in tourism}

Sönmez et al. (1994) defined tourism crises as situations that can threaten the normal operations in the tourism industry and damage the destination's reputation and image. Such crises are often the manifestation of problems derived from on-going or sudden changes, and the failure of tourism business and destination managers to adapt to them (Faulkner, 2001). Research on crisis management in the travel and tourism literature is abundantly dedicated to the planning and design of institutional programs from the perspective of tourism destination managers and governmental or quasi-governmental entities, such as destination management organizations (DMOs) or convention and visitor bureaus (CVBs) in destinations (Mair et al., 2016; Ritchie, 2004). Within this stream of research, marketing-related investigations have focused the attention on broad, large-scale recovery strategies to address diverse crisis situations damaging the image of tourism destinations, like war and terrorism (see Bar-On, 1996; Sönmez et al., 1999), natural disasters (see Faulkner, 2001; Huang et al., 2007) or health and epidemic outbreaks (see Plog, 2006; Speakman and Sharpley, 2012) that generate risk and safety concerns on potential visitors. Among the various types of risks for travelers, human-induced risks include terror, political instability and crime (Fuchs and Reichel, 2006). Within this latter category, criminal risk generally refers to physical harm and property-financial crimes (Simpson and Siguaw, 2008), which are reflected on particular psychopath behaviors such as robbery, kidnapping, sabotage and other felonies that often affect tourists (Santana, 2003).

One manifestation of criminal activity that occurs in certain geographies is that related to the business of illegal drugs controlled by trafficking organizations and cartels, which in turn can significantly influence the crime rates in destinations visited by tourists (Brunt et al., 2000) but has received scant attention in the tourism crisis literature. Unlike small-scale, isolated cases of delinquency such as simple robbery and theft, criminal activity controlled by drug syndicates has greater impact and is a more complex societal problem, given that the nation-state is challenged by transnational organized criminal groups (McElroy, 2006; Shelley, 1995). As a consequence, tourism regions suffering a poor image associated to drugcartels presence, high crime rates, violence and risk issues usually experience dramatic downturns in tourist arrivals (Tilson and Stacks, 1997). In such crises, while visitors might not be the main or only targets of criminals at tourism destinations, the occurrence of felonies have negative effects on potential and actual travelers because crimes often take place on streets and locations such as shopping malls, leisure facilities and other highly busy entertainment and tourism areas, including hotels and other hospitality establishments (Zhao and Ho, 2006).

A number of conceptual and empirical works on crisis management with particular emphasis on the hotel industry can be found in the literature. For instance, Wang and Ritchie 
IHR

36,1
(2010) developed a strategic model to explain the factors that influence crisis planning in the hotel context. Israeli et al. (2011) studied management practices across various functional areas for crises affecting India's luxury lodging segment, while Campiranon and Scott (2014) identified critical success factors for effective crisis management in hotels of Thailand. Research by Kuo et al. (2017) employed longitudinal data of hotels' performance in Taiwan to develop a framework with parameters to forecast "time to recovery" that can be used for crisis planning. Ritchie et al. (2011) also examined crisis planning in the Australian accommodation industry, concluding that organizational type and size had an impact on the implementation of planning and preparedness. However, given that crisis research in tourism and hospitality is largely focused on planning and evaluation, it is necessary to better understand crisis response and market recovery, rather than just prevention (Carlsen and Liburd 2007; Fuchs and Reichel, 2011). This is especially important for hotels and hospitality firms located in insecurity-stricken destinations where a sudden surge of crime and violence take place, since such crises that can threaten customers and employees, and endanger the business' financial status and future viability (Ritchie et al., 2011; Santana 2003).

Some studies have been conducted focusing specifically on insecurity and crime in the context of hotels. For example, a study by Ho et al. (2017) reviewed police reports of MiamiDade County, Florida, showing that the three major criminal activities carried out against hotel guests were property-related: theft, burglary and car break-in. More recently, Leung et al. (2018) analyzed TripAdvisor reviews of crime-related hotel experiences, classifying the types of hotel crimes and their impact on guests' fear of crime. The most common types of crimes reflected in online reviews were property (robbery, theft, auto burglary), statutory (drug-related, prostitution) and personal crimes (assault, shootings, murder). With respect to the attitudes of travelers toward hotel security measures, Feickert et al. (2006) conducted a study of hotel guests in the United States about their acceptance of certain security features. Overall, survey respondents were favorable to nonintrusive security measures, while younger respondents and women were more likely to accept stringent security measures. Similarly, Rittichainuwat (2013) assessed tourists' perceptions toward overt safety measures in hospitality services in Thailand. Results showed that too stringent security measures could frighten tourists because such measures could create a perception of alarm, recommending hoteliers to find an appropriate balance in using overt safety measures so as not to scare guests.

Another vein of research has concentrated on the specific features implemented to deter crime and enhance security in hotel properties. Enz (2009) investigated the safety and security features of 5,487 hotels of the United States, finding that upscale, larger hotels in urban and airport locations tend to offer higher safety and security levels, as well as higher advertised rates. According to the study, the most common types of security measures adopted by hotels consist of features such as electronic locks, in-room safes, interior corridors or safety materials and videos, which are similar to those implemented in reaction to terrorism situations (Enz and Taylor, 2002; Taylor and Enz, 2002). Nevertheless, the literature on hotel responses to personal risk, crime and insecurity has been oriented to study the adoption or enhancement of product-related features, neglecting the role of other marketing mix activities (e.g. distribution, pricing and promotion). Thus, considering that marketing is one of the key primary businesses functions to effectively manage crisis and risk contingencies (Engemann, 2018), a focus on the wider marketing mix practices is necessary in order to better understand the strategies implemented by firms in the lodging industry at destinations perceived as unsafe by travelers.

\section{Marketing mix in the hotel sector}

Although it represents one of the earliest frameworks that emerged in the marketing literature (Borden, 1964), the study of marketing mix activities continues to be of interest in 
the broad marketing discipline (see Blut et al., 2018; Datta et al., 2017), as well as specifically in the hospitality field (see Kim and Kim, 2018; Kwok et al., 2020). For simplicity and pedagogical purposes, the marketing mix elements were initially categorized into what is known in the academic literature as the 4 P's: product, place (distribution), price and promotion (communications). Each of the four categories subsumes a number of more specific, tactical activities available to the firms for the operational execution of broader marketing strategies (Van Waterschoot and Van den Bulte, 1992). Indeed, many of the seminal business and management strategy concepts and theories that are used to date were originally based on the marketing mix framework (Shaw, 2012). Accordingly, the deployment of marketing mix activities is critical to enable business programs and to support the overall firm strategy, as a way to build and sustain competitive advantages for the firm (Hunt, 2010; Kumar, 2018).

The marketing mix framework has been also adapted to tourism and hospitality settings (Kotler et al., 2016; Lewis and Chambers, 2000; Meidan, 1984), including organizing and breaking down the mix classification into special elements that may fit particular services characteristics (Bojanic, 2008). The marketing efforts and activities corresponding to the marketing mix elements, when combined and implemented adequately, are positively associated with financial and operational business performance in the lodging sector (Cizmar and Weber, 2000; Radišić et al., 2010). Therefore, a better understanding of the marketing mix as a management tool is needed to learn how tactical actions are used by practitioners (Constantinides, 2006; Mintz and Currim, 2015), especially as the occurrence and severity of uncertain, turbulent environments of crisis have increased over recent years in the tourism and hospitality industry (Ritchie and Jiang, 2019).

Extant research on the implementation of marketing strategies/tactics for crises in travel and hospitality are fragmented, generally focusing on isolated elements of the marketing mix: products and services (e.g. Fawzy, 2010; Israeli et al., 2011), distribution (e.g. Cavlek, 2002), communication (e.g. Campiranon and Scott, 2014; Dahles and Susilowati, 2015) or pricing (e.g. Israeli et al., 2011; Kim et al., 2019; Lynch, 2004). With respect to specific research related to marketing mix in hotels at destinations perceived as unsafe by travelers, only few studies are found in the literature. For instance, Salman et al. (2017) investigated the marketing activities of hotels in Egypt in the context of instability after the Arab Spring crisis, proposing a marketing mix model for crisis response. However, because of the quantitative-based model approach utilized, the study did not report the specific marketing mix practices implemented by management, recommending investigating additional variables in the marketing mix. In a similar setting, research by Masa'deh et al. (2018) examined the promotional mix practices and performance of hotels in Jordan in the context of political crisis in the Middle East. Yet, the authors only studied the role of advertisement, website and direct sales, so further research was suggested including more elements of the marketing mix. Thus, a more holistic approach is needed when investigating the elements of the marketing mix in hotel contexts, considering all the components of the marketing mix and other influencing factors (Loo and Leung, 2018).

To the best of the author's knowledge, no published research has specifically studied lodging industry's responses in terms of the four categories of marketing mix tactics employed at destinations suffering a risk crisis due to large-scale organized criminal activity. Thus, as explained in the next section, this investigation explores the marketing mix implementation of hotels located in a region stricken by drug cartel-related violence at the US-Mexico border, a research context that is geographically, temporally and contextually unique in the tourism crisis literature (Pennington-Gray, 2018) and requires further attention given the severity of crime and insecurity as a growing phenomenon in tourism destinations across various geographies such as Latin America (Monterrubio et al., 2020; Tarlow, 2014). 
IHR

36,1

\section{Empirical study \\ Method}

In order to conduct this investigation, a case study approach was followed as a way to explore and understand the phenomena of interest in its unique location, environment and context (Daymon and Holloway, 2011). Case studies are useful in tourism studies when the objective is to discover and propose relationships of phenomena "directly related to a site, organization, or locality under scrutiny" (Xiao, 2010, p. 122), as in the case of this research setting in which drug-related violence affects a particular geography. One way to gather data in case studybased research is thorough interviews that allow to bring forward viewpoints of key actors and informants who are responsible for the decision-making in the entities under study (Aaltio and Heilmann, 2010). Thus, interviews with hotel general managers/directors and marketing managers were conducted as recommended to investigate tourism service providers in relation to safety and security issues (Rittichainuwat and Chakraborty, 2012). Given their iterative nature and adaptability to a wide range of themes and topics, interviews are appropriate for exploratory research and are particularly useful to elicit information from tourism managers and practitioners who are often very busy to respond conventional surveys (McGehee, 2012).

\section{Context: US-Mexico border}

Two neighboring destinations along the US-Mexico border were selected to study the marketing mix practices implemented by lodging firms when coping with the effects of violence and insecurity events. McAllen, in the state of Texas (United States) and Reynosa, in the state of Tamaulipas (Mexico) are part of the region known as the "Borderplex" in the lower Rio Grande Valley. Together, the two sister cities belong to a binational metro area which has traditionally constituted a major commercial and tourism region, where nationals from the US regularly cross the border's international bridges to visit Mexico and vice versa (Fullerton and Walke, 2014; Sandoval-Hernández, 2008; Baruca and Zolfagharian, 2013).

However, the area is located in one of the principal northbound drug trafficking corridors into the United States (see Figure 1) and is also a major route for smuggling weapons from the United States to the south of the American continent (Correa-Cabrera, 2013). Beginning 2010, a grim war among cartels to control the cities at the Mexico-US border flared up in the midst of military actions and counternarcotics operations by Mexico's federal government to dismantle criminal organizations (Sánchez-Munguía, 2011). As kingpins and big bosses were jailed or killed, the cartels fragmented into smaller organizations that expanded their criminal portfolios beyond drug trafficking to include other crimes such as extortion, kidnapping, human trafficking, money laundering, among others (Ferreyra, 2015). Similarly to what happened at other Mexican tourism destinations with high cartel-related criminal activity (de la Torre and Navarrete Escobedo, 2018), visitors to the border became affected either directly as victims of kidnapping, carjacking and robbery, or indirectly through shootings or narcoblockades on the roads, which heightened a sense of risk and fear for traveling to the area.

The US government intensified advisories to its citizens about the potential hazards of highway travel in the state of Tamaulipas (Department of State, 2011) and continued to launch "Level 4: Do Not Travel" warnings in the following years due to persistence of risk (Department of State, 2018). Thus, the cartel-related violence along the border negatively impacted travel and tourism to Mexican border sites perceived dangerous (Bussey, 2012; Fullerton and Walke, 2014; Sánchez-Munguía, 2011). Further, a "spillover" effect into the southernmost part of Texas also generated a sense of risk and insecurity on the US side of the border (Simpson et al., 2014). Thus, the selected region is appropriate to study the marketing strategies/tactics employed during crime-related insecurity crises in the hotel industry. 


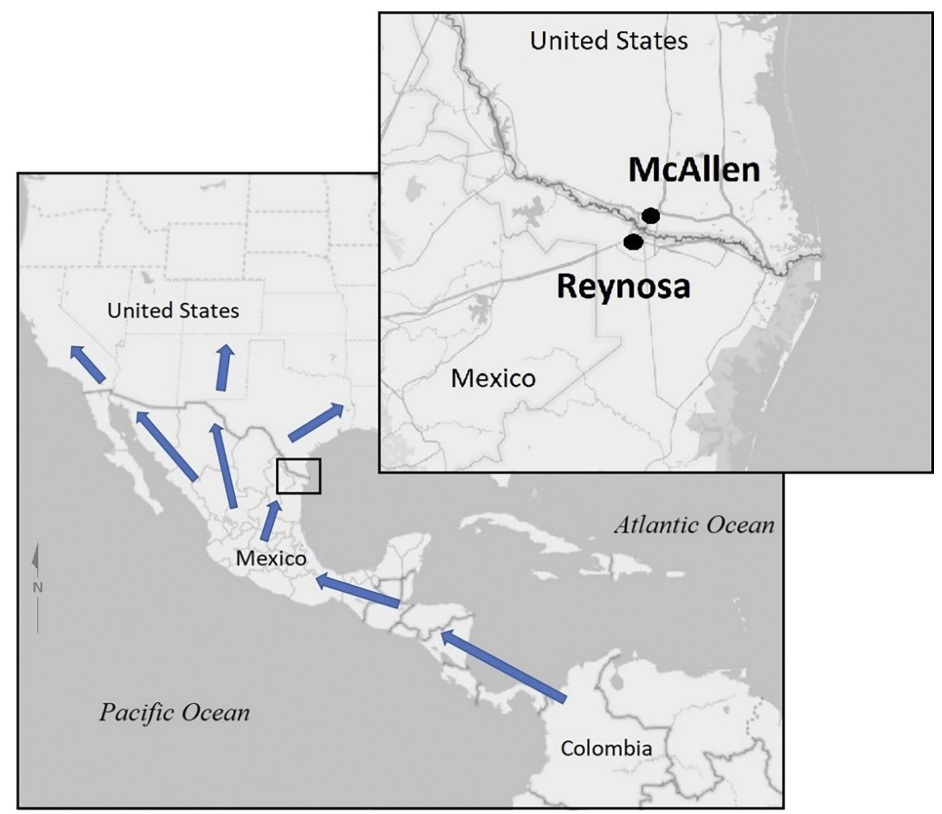

Major drug trafficking mainland routes into the United States
Hotels' marketing mix responses

137

\section{Interviews}

An interview guide was first developed by reviewing the existing literature in order to "establish the domain the interview will explore" and come up with "a list of topics for which questions must be prepared" (McCracken, 1988, p. 31). Derived from the literature review and with suggestions and inputs from academic researchers with experience on the topic, the interview guide was structured in three parts to learn about: (1) the firm's general marketing strategies (i.e. competitive advantage, target markets, value propositions) and the use of marketing mix tactics (i.e. product-service, communication, distribution, pricing) implemented before the insecurity crisis; (2) the strategies and marketing mix modifications or changes made to cope with the risk and insecurity situation; (3) the view of managers about the role of local tourism organizations, governments, as well as the media coverage of negative events in the area and the relation to the hotels' marketing efforts and crisis responses.

As in previous works of the literature in which elicitation from key informants was necessary to understand marketing decisions within firms (e.g. Ardley, 2008), personal interviews were requested to 25 managers of different hotels in the bi-national border region. As a result, 14 face-to-face, semi-structured interviews (eight on the US side, six on the Mexican side) were conducted with managers who had been in the position an average of 6.1 years. The mean size of the hotels was 117 rooms, and the average year of the hotel openings was 1993. The number of interviews is consistent with the purposive sampling used in research with homogeneous groups of informants (Daymon and Holloway, 2011) and with previous works in the tourism and hospitality literature (e.g. Green et al., 2003). All questions and answers were audio recorded, focusing on the main topics of inquiry but including probing and follow-up questions in a "tree and branch" pattern, in such a way as to reach thoroughness and informational saturation (Rubin and Rubin, 2005). 
IHR

36,1

138

The interviews were conducted at the end of 2011 and beginning of 2012, which corresponds to the period on which the region was most drastically affected, hardest-hit by the cartels' war. The most intense wave of narcoviolence surged in the state of Tamaulipas between 2010 and 2013, provoking the worst, long-lasting impacts on tourism and commercial activities in the Reynosa area (Zárate-Ruiz and López-León, 2016). Following the outbreak of insecurity and criminal violence in 2010, overall tourism activity in the state decreased over one-third, about $20 \%$ of restaurants went out of business, and hotel industry fell around 30-35\% (Correa-Cabrera, 2013). The most severe reduction of international visitors to Mexico's border occurred in $2010(-10.4 \%)$ and $2011(-8.6 \%)$, together with a drop in Mexican highway traffic from large cities like Monterrey to the Reynosa-McAllen border in $2010(-19.5 \%)$ and $2011(-9.2 \%)$. This represents the steepest contraction of travel volumes in more than a decade according to official tourism data (Secretaría de Turismo, 2018) and coincides with the period of highest crime rates in Tamaulipas (Secretaría de Seguridad y Protección Ciudadana, 2020). As for the effects on the US side of the border, the dynamics of visits and travel spending by Mexican nationals in the McAllen area during the same period can also be attributable to the fluctuation of violence on neighboring Reynosa (Nivin, 2013).

\section{Analysis}

The interview transcripts and notes were analyzed in a deductive or "top down" form, by organizing the data into categories as a way to transform raw data into manageable blocks, operationalized information easier to interpret (Altinay and Paraskevas, 2008). Participants' responses were classified into the marketing mix elements derived from the hospitality and tourism marketing literature according to the categories in Table 1. The marketing activities implemented by hotels were coded into the major themes equivalent to the four theoretical and conceptual components of the marketing mix (4 P's), which were further broken down into subthemes and more particular items corresponding to the specific actions that managers declared were implemented in response to a decrease in hotel guests due to the perceived insecurity in the area. The marketing activities were analyzed and categorized by two independent judges with experience in hospitality and tourism marketing research. This procedure is consistent with other marketing mix categorizations conducted in hospitality marketing research contexts (e.g. Loo and Leung, 2018). The percentage of agreement into the marketing mix components was $79.1 \%$, and discrepancies were resolved through discussion until a final consensus was reached.

The collection of coded data was examined through an iterative process to identify patterns/groupings and relationships, directing the focus and attention to frequencies, similarities and contrasts in the coded content (LeCompte and Schensul, 1999). To avoid premature closure, the analysis moved through a succession of stages starting with "codes directly derived from the data, through to more abstract or second level categorical codes, and finally to the last stage of conceptual and theoretical codes" (Goulding, 1998, p. 55). This allowed not only to ascertain the implementation of the marketing mix according to its theoretical/conceptual elements, but also to learn directly from the hotel managers answers the context of external factors that influenced their decisions by integrating the various components, constituents and structures extracted from the interviews (Altinay and Paraskevas, 2008; LeCompte and Schensul, 1999).

\section{Findings and discussion}

Effects of insecurity on lodging demand

The majority of managers interviewed acknowledged that the years prior to 2010 were the most prosperous and profitable for the lodging sector in the region. This was largely driven 


\begin{tabular}{|c|c|c|c|}
\hline Marketing mix & Definition & Examples mentioned & \\
\hline Pricing & $\begin{array}{l}\text { Combination of prices used by the firm to } \\
\text { represent the value of the offering. The } \\
\text { pricing impacts how the customer values } \\
\text { what is being offered and what is received }\end{array}$ & $\begin{array}{l}\text { Price reductions, discounts, payment } \\
\text { options and value-added bundling }\end{array}$ & mix responses \\
\hline Communication ${ }^{\mathrm{b}}$ & $\begin{array}{l}\text { All communications between the firm and } \\
\text { the target market that increase the } \\
\text { awareness of the product/service mix or the } \\
\text { presentation mix, that establish or monitor } \\
\text { consumer expectations, build relationships, } \\
\text { or that persuade consumers to purchase }\end{array}$ & $\begin{array}{l}\text { Advertising, public relations and publicity, } \\
\text { database/direct marketing, personal sales, } \\
\text { merchandising, alliances or partnerships }\end{array}$ & \\
\hline Product/service & $\begin{array}{l}\text { Combination of goods and services, } \\
\text { whether free or for sale, that are factually } \\
\text { offered to satisfy the needs of the target } \\
\text { market. Included in this category are the } \\
\text { elements used by the firm to increase the } \\
\text { tangibility of products and services in the } \\
\text { perception of guests, and how such goods } \\
\text { and services are presented for the customer } \\
\text { to sense }\end{array}$ & $\begin{array}{l}\text { Guest rooms, food and beverage venues, } \\
\text { furniture, swimming pools, sauna, exercise } \\
\text { equipment, linen tablecloths, china and } \\
\text { silverware, other amenities. Physical plant, } \\
\text { ambiance and atmospherics, courtesy of } \\
\text { staff }\end{array}$ & \\
\hline Distribution & $\begin{array}{l}\text { All channels available between the firm and } \\
\text { the target market that increase the } \\
\text { probability of getting the customer to the } \\
\text { product. This is how the customer can buy } \\
\text { and use the services offered }\end{array}$ & $\begin{array}{l}\text { Central reservation systems, wholesalers, } \\
\text { travel agents, Internet reservation } \\
\text { websites, phone books, directories and } \\
\text { yellow pages }\end{array}$ & \\
\hline \multicolumn{3}{|c|}{ 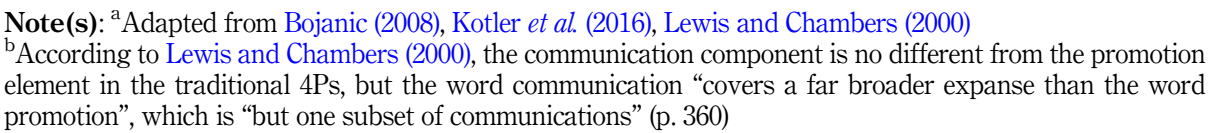 } & $\begin{array}{l}\text { Table } 1 . \\
\text { The hospitality } \\
\text { marketing mix }\end{array}$ \\
\hline
\end{tabular}

by the economic boom in retailing and import/export-related activity in the US border area, and the manufacturing or maquiladora industry and heavy natural gas extraction on the Mexican side area. For example, a hotel in Reynosa had most of its business from energy and natural gas contractors that were working with PEMEX (the Mexican state-owned oil company). The general manager declared that demand for rooms was so high, "that we didnt have to place much emphasis on marketing." However, he regretted that "it was a mistake" not to diversify their sources of business, because they "put all the eggs in a single basket," so in the following years when there was a sudden drop in rooms occupancy, it was difficult to get customers. All other hotel managers also recognized that travel and tourism in the region had been dramatically affected since the beginning of 2010 with a surge in cartel-related violence in Tamaulipas. The phenomenon also impacted hotels in McAllen, as one informant noted: "We felt the demand reduction when Mexico started having problems." When asked about the decrease in visitors, informants' first answer was that insecurity issues caused fear to travel. One interviewee lamented that "fewer American companies. . . are renting rooms in Reynosa, compared as it used to be before."

A large proportion of Mexican visitors shopping in McAllen do so by driving their own vehicles from cities in the interior of Mexico, but highway travel sharply dropped because of fear of assault or robbery on Mexican territory. Since 2010, many of those who still travel for shopping prefer to stay in McAllen, rather than Reynosa. As one of the hotel managers in Reynosa recalled: "during Black Friday weekend we were full because guests stayed here to cross and shop in the US, but in these last two years that has not happened." On the same issue, one of the hotel managers in McAllen expressed that for Mexican visitors, "crossing the 
IHR

36,1

border is almost like a relief. . . it's the fact that people wanna get to the border" side on the US where they feel safer. Yet, those still traveling have also suffered lawlessness, as another manager in McAllen said: "I've personally had experiences with customers who tell me that they are lucky to be here", because on the Mexican highway criminals "took away the truck, credit cards. . . they are lucky to be alive!".

However, the reduction of hotel stays in Reynosa did not necessarily mean an increase in occupancy for McAllen's hotels. For instance, one of the managers pointed out that their international segment (mainly guests from Mexico) was greatly decimated in the previous two years: "Mexican violence started affecting us and deeply impacted our business" because "people used to drive Friday nights from Monterrey after work, but they dont do that anymore," she added. As illustrated by informants' accounts, the overall impact of Mexican nationals who stopped traveling was proportionately greater on hotels of Reynosa than McAllen, but no general increase in occupancy was felt on the US side either. As described by another general manager of a budget hotel in McAllen, in 2009 they had "about $80 \%$ occupancy on average, and this year about $7 \%$ less than the previous year, and even less than the year before."

\section{Marketing mix practices}

The marketing mix practices implemented by lodging firms during risk and insecurity crisis are shown in Table 2 . The first column corresponds to the four marketing mix elements, and the derived tactics and actions on the second column correspond to the specific activity employed by hotels. The last column shows the percentage of informants reporting the implementation of each type of activity. Such frequencies and tabulations are presented to better communicate the results of categorizing unstructured, qualitative data that serves as a basis to further elaborate on the factors that are influential for the marketing mix implementation, following an approach that is usual in qualitative-based research (Bryman, 2006; Fakis et al., 2014; Kerlinger and Lee, 2000). Thus, statistical generalization should not be inferred from the percentages displayed, which are "intrinsically local" to the case study context (Maxwell, 2010, p. 479).

Most hotels reacted by making adjustments to the pricing element in the marketing mix. The majority of such tactics consist of price drops in the form of reduced or discounted rates, as well as weekly rates; value added, where existing products or services became free (i.e. breakfast, transportation); in some cases, price bundling (i.e. all-inclusive plans); and credit extension for payments (for corporate accounts). In this regard, a manager of a hotel in McAllen recalled: "We cannot demand the rate that we normally could because less people are coming... what happened is that everybody went down on their rates" (referring to the competition). She added: "We are all going after the same customers, and unfortunately there was not enough to go after, so what we did is we had to lower our rates in order to try to shift them (customers) from other properties. . . and it worked, our occupancy went up, but we had to sacrifice rates." Hotels that did not target diversified market segments before the insecurity crisis became highly vulnerable to price reductions later on. For instance, one informant said that when demand was high, they "neglected other segments," but when they wanted to recover them "it was difficult and late," so they had to lower rates.

Several hotel properties engaged in one or more communication activities in response to the drop in hotel demand. Half of the respondents used some form of advertisement, either in newspaper, magazines or radio, online advertisement, billboards and outdoor posters and signs or through sponsorship at sport events. However, some of the interviewees expressed doubts about the effectiveness of such measures. One manager of a McAllen hotel commented that billboards on the highway to the border "did not contribute" to more guest arrivals, so they "stopped doing it." Another hotel manager in Reynosa said: "Newspaper is expensive 


\begin{tabular}{|c|c|c|c|}
\hline Elements & Tactics/Actions & $\begin{array}{l}\% \text { Of hotels that implemented } \\
\text { activities }^{\mathrm{a}}\end{array}$ & $\begin{array}{l}\text { Hotels' } \\
\text { marketing }\end{array}$ \\
\hline \multirow[t]{7}{*}{ Pricing } & Price drop & & \\
\hline & Reduced or discount rate & 78 & \\
\hline & Weekly rates & 7 & \\
\hline & Bundling & & \\
\hline & $\begin{array}{l}\text { "All Inclusive" packages } \\
\text { Credit }\end{array}$ & 14 & 141 \\
\hline & $\begin{array}{l}\text { Extended credit time for payment (corporate accounts) } \\
\text { Value added }\end{array}$ & 7 & \\
\hline & $\begin{array}{l}\text { Existing product provided free now (i.e. breakfast, } \\
\text { transportation) }\end{array}$ & 14 & \\
\hline \multirow[t]{14}{*}{ Communication } & Advertisement & & \\
\hline & Advertisement in newspaper, magazine or radio & 50 & \\
\hline & Online advertisement & 14 & \\
\hline & Sponsorships and sport events & 14 & \\
\hline & Billboard on highways or airport & 21 & \\
\hline & Sales promotions & & \\
\hline & Special offers for locals during holidays & 21 & \\
\hline & Giveaways and loyalty programs & 7 & \\
\hline & $\begin{array}{l}\text { Redirect sales efforts to new segments (i.e. sport teams, } \\
\text { schools, government, churches) }\end{array}$ & 50 & \\
\hline & Increase visits/calls to existing clients & 35 & \\
\hline & Trade shows, fairs, expos & 7 & \\
\hline & Public relations/Publicity & & \\
\hline & Gatherings with business and community members & 14 & \\
\hline & Use of social networking (i.e. Facebook) & 21 & \\
\hline Product/ & New products/services & & \\
\hline \multirow[t]{3}{*}{ Service } & $\begin{array}{l}\text { New product offered in the stay } \\
\text { Improvements }\end{array}$ & 28 & \\
\hline & Security-related features (i.e. cameras, door locks) & 14 & \\
\hline & $\begin{array}{l}\text { Nonsecurity-related features (i.e. personalization of items, } \\
\text { food and beverages) }\end{array}$ & 21 & \\
\hline \multirow[t]{4}{*}{ Distribution } & Online travel agencies (OTA) & & \\
\hline & Reinforcement and concentration with OTAs & 28 & \\
\hline & Wholesale and global distribution systems (GDS) & & \\
\hline & $\begin{array}{l}\text { Reinforcement and concentration with GDS, wholesalers } \\
\text { and consortia }\end{array}$ & 14 & \\
\hline \multicolumn{3}{|c|}{$\begin{array}{l}\text { Note(s): }{ }^{\text {a }} \text { The percentages do not add up to } 100 \% \text { because some hotels implemented more than one type of } \\
\text { activity within the same marketing mix element, while other hotels did not implement any type of activity in } \\
\text { some marketing mix elements }\end{array}$} & $\begin{array}{r}\text { Table } 2 . \\
\text { Marketing mix } \\
\text { practices identified }\end{array}$ \\
\hline
\end{tabular}

and didn't work out... (advertisement) seems not to work significantly, because as long as there is perception of insecurity, no advertisement can work well."

Also, informants expressed that personal sales was a key tactic employed during previous months, including redirecting sales efforts to new market segments (i.e. sport teams, schools, government, churches), increasing visits/calls to existing clients and attending trade shows, fairs and expos. As one manager declared: "The best way that I still believe to sell a hotel is just to get out and meet people... just doing it the old-fashioned way, you wanna shake hands." Similarly, another general manager detailed that "the goal for the Sales Department is to make at least 40 visits per week with companies and prospective clients" and "80 effective calls weekly... hard sales are what sell, beyond other types of advertisements." 
IHR

36,1

Another tactic used was public relations and publicity, as reflected in activities such as participating in business and community events, without investing money in advertisement. A respondent emphasized "being involved in your communities, get involved in the events: Rotary Clubs, American Legions, Habitat for Humanity... be a part of all of this." Additionally, social networking (i.e. Facebook) was used to keep communication with past guests and their contacts to foster positive recommendations. This tactic was a recurring theme in the conversations with informants, stressing the "focus on mouth-to-mouth through social networking, mainly for local guests, for restaurants." Less frequently, hotel managers mentioned sales promotions, represented by special offers during holidays, giveaways, and loyalty programs for guests.

The interviews suggest that the type of property ownership influences the extent to which the communication mix is used by hotels. Franchised hotels implemented more communication tactics than corporate-owned, probably because the former have more flexibility than the latter, especially in making decisions about some types of advertising or sales promotions. As one manager at a corporate-owned hotel mentioned, she was not too involved in advertisement because "that is handled at the corporate level." Nevertheless, hotels with no brand affiliation were perhaps the least engaged in communication activities than brand-affiliated properties. For instance, an independently-owned hotel manager considered "requesting government support for funding ad campaigns in the media" because it was something that the business needed to strengthen.

Marketing mix elements for product/service and distribution were not mentioned as frequently as the other mix elements. Product/services were discussed in few cases, in the form of new product and services offered in the stay or improvements in security-related features (i.e. cameras, door locks) and nonsecurity-related features (i.e. personalization of items, new food and beverage menus). Distribution was reflected in greater engagement with online travel agencies (OTAs) and by increasing rooms' reservations through wholesalers and global distribution systems (GDS). The scarcity of product/service tactics could be attributable to the difficulty to modify hotels' fixed product, such as rooms, facilities and physical plant. As for distribution, the channels are primarily the same for all the competitors in the areas' lodging market.

The magnitude of the investment necessary to change or improve hotel core products/ services hinders such modifications. One informant explained that his old property required renovations but recognized that "because there is not enough budget," no improvements or remodeling were made. Another manager mentioned that recent product adjustments in her hotel consisted on just small changes to the restaurant's menu and some redesigned features in the rooms, but "they were scheduled modifications carried out throughout the hotel chain at the national and international level." Again, the type of property ownership also seems to influence the use of distribution channels. Two independently-owned hotel managers said that no new distribution tactics were implemented, while another had recently terminated a franchise contract with an international chain, without new distribution mix activities under consideration.

\section{Tourism organizations and government entities}

Managers of both US and Mexico hotels expressed contrasting views regarding the marketing and promotional efforts by tourism bureaus and organizations to stimulate travel to the destinations. Informants in Reynosa felt that the local government and tourism chamber did little to reactivate visitation: "Government agencies have done nothing to foster tourism. Only few events have been done to bring travelers, (but) they have no budget. . TV spots would be helpful." Likewise, another informant declared: "that's 'crumbs' because it's too little.... the local authorities and organizations can do very little”. However, some 
festivals and entertainment events were organized in Reynosa by local authorities and business organizations. In that regard, a respondent considered they "are doing events so that people recover trust," while "there are plans with the Hotel Association and the Chamber of Commerce, to launch free cross-border transportation and a medical directory" to attract medical tourism.

Managers of McAllen hotels suggested that city tourism efforts were positively impacting tourism inflows. An informant noted: "Their role is hard and difficult because they cannot get involved in crime reduction directly. But they have been organizing events, trade shows and expos that bring occupancy to the hotels". Another interviewee commented that "the Chamber of Commerce worked to establish private flights from Mexican cities to this area", and one more praised that they are "part of the team to promote the city, the hotels... they are always promoting the shopping, they are promoting the mall. . . by advertising."

Overall, managers in McAllen commended the promotion of conventions and large group meetings in the area by the Chamber of Commerce: "They have a small team of people that are hired to go out to market the city for conventions. But they dont have enough budget. . . we need more conventions. It seems that they dont have a big plan for the future". Another manager added that "they are crucial for 'selling the city'... they advertise in Mexican newspapers, announce new store openings, try to bring movies or shows to be filmed in the zone" to augment the hotel room demand.

\section{News media and tourism flows}

Points of view about the role played by the media and its coverage of violence-related news were divided. Some informants expressed that although risk situations and violence occurred in the area, those were frequently exaggerated by the media: "They have stories that will be probably bigger than it really is". Managers realized there is an insecurity problem, but "the media magnified the (violent) events", a view supported by another manager considering that "travelers. . . that hear the news are afraid to come, (but) some were "urban legends"'. They explained the news coverage on the grounds that "they (TV channels) are in the entertainment" business, and "have 'yellow' content in excess, compared to other positive news, because it's their business". In the words of one respondent, "they sell by showing the pictures of the worst things they can show". According to a McAllen informant, "people for example from Chicago or Washington may not come down here. . . so definitely the media is impacting". To illustrate, another manager said that 'Border Wars', a National Geographic television show about US agents protecting the border from criminals, has affected the image of the area because "they basically show the Mexican traffickers... everybody mentions it."

On the other hand, various informants viewed news reports as accurate, expressing that "they (the media) are portraying things just the way they are; no more, no less." A Reynosa manager declared: "Things were not exaggerated by the media, because I have seen what happens..." (pointing out to the street in front of the hotel). Indeed, other informants considered cartel-related insecurity to be understated in the news because government and news agencies, even in the US, did not reveal the real degree of the problems: "They put the foot over (hide it) so we don't hear about."

Beyond different opinions about the media's accuracy, hotel managers generally agreed that news and television coverage of criminal violence had direct impact on a reduction of travelers: "The degree of killings in the way these people are getting killed, yeah, definitely contributes." Yet, some informants pointed out that, if positive, media coverage can bring benefits to the area's tourism industry. For one of the McAllen managers, "other notes have had positive effects, like newspaper articles in Monterrey about visitors gaining confidence to drive on the highway again," which he said has helped to a slight increase in Mexican tourists. 
IHR

36,1

\section{4}

While informants referred in general to TV and radio news coverage, they also acknowledged the increasing role played by the word-of-mouth and online social media. One manager said that "media is important, but word-of-mouth may be more critical because violent events that are not reported are transmitted from people to people" through online communication. In that respect, another manager underscored that "what people experience by themselves" influences their personal communication and formation of an image of the area.

\section{Proposed marketing mix framework}

The analysis of marketing mix practices and factors that influenced the informants' decisions led to a framework with the studied elements and relationships shown in Figure 2. The emergent scheme illustrates that the deployment of marketing mix activities can be grouped into those that are more intensively implemented, namely the pricing and communication elements, and those that are less intensively implemented, the product-service and distribution elements.

As reported before (Table 2), most informants declared a frequent use of marketing mix tactics under the elements of pricing (e.g. price drops) and communication (e.g. advertisement and direct/personal sales). There was a less frequent use of marketing mix tactics related to the elements of product-services and distribution channels. The framework also reflects the influence of internal factors such as target market diversification, type of ownership or magnitude of investments required, as well as the external influence of tourism promotion organizations, the media and tourists flow volumes in the context of insecurity and risk perception:

(1) The diversification (or concentration) of target market segments influences the pricing policy. As revealed from the interviews, those hotels that prior to the violence outbreak were concentrated on few target markets (i.e. gas contractor-related business travelers or shopping visitors), after 2010 during the crisis felt more pressure to lower room rates to make up for the reduced guest arrivals. This is consistent with findings of Campiranon and Scott (2014) in that combining different target markets increases revenue generation in crisis situations, especially when such combination includes travelers with low levels of risk-aversion. As noted by Dolnicar et al. (2012), such "crisis resistant" segments "are highly attractive to the tourism industry because they have the potential to reduce vulnerability to unpredictable external shocks" (p. 75).

(2) The type of ownership (franchised vs corporate-owned) influences the communication mix tactics and the distribution channels that hotel firms employ. Managers of

Figure 2.

Marketing mix framework

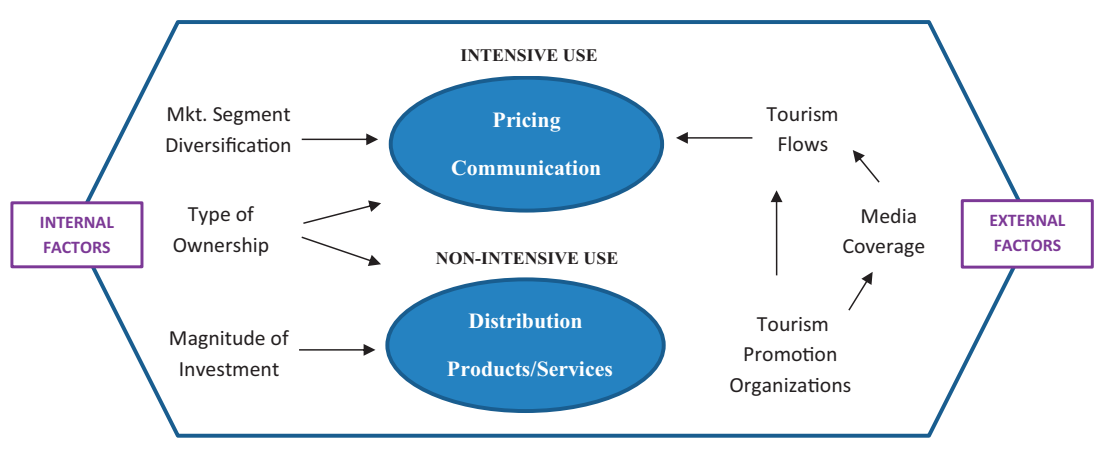


corporate-operated properties expressed they were restricted in the advertising or promotion they could do (e.g. subject to corporate-level budget decisions), whereas managers of franchised properties enjoyed more autonomy to make expenditure decisions. Interestingly, independently-owned hotels carried out even less communication than brand-affiliated properties. Further, franchised or corporateoperated hotels with brand-affiliation tended to use a wide variety of distribution channels, such as telephone central reservation systems, GDS, OTAs, while independently-owned hotels without affiliation to a well-known brand mainly relied on telephone or e-mail reservations. As shown in the literature, the type of ownership is a key factor shaping the administration of hotels (see Rushmore, 2002; Stutts and Wortman, 2006).

(3) The magnitude of the investments required for improving products or services influences whether such changes are made or not. Most informants commented that major improvements or remodeling to the core product (e.g. hotel rooms, facilities) were not implemented because such capital expenditures require considerable budget planning, usually scheduled every six to seven years. The few hotels that implemented any change in products-services were only for small or moderate expenditures in nonsecurity-related items (e.g. personalization of logos in key cards, modification of certain restaurant offerings) or security-related features (e.g. cameras, door locks), suggesting that minimal effort was taken by the properties to increase a perception of security. According to Claver-Cortés et al. (2006), improved facilities are associated to better hotel performance, so firms in need of external funds should seek financial support that is often available to businesses as part of governments' crisis response policies (Ritchie and Jiang, 2019). In the case of Mexico, funding and support programs for the tourism industry are typically available from the government at the federal level (Cruz-Milán, 2017), rather than from local governments which frequently have more limited budgets.

(4) Coordinated promotional activities by tourism organizations/government support the hotels' marketing efforts to attract higher volumes of tourism flows. Managers recognized the benefits of building reciprocal relationship between hotels, tourism entities/chambers of commerce and local authorities. These are usually established through coordinated strategies such as festivals, trade shows and joint communication programs (e.g. co-op advertising, public relations campaigns). In line with the tourism crisis literature, the industry's coordination with tourism quasigovernmental entities can help to improve the image of troubled destinations as a way to foster recovery and visitation (see Faulkner, 2001; Fuchs and Reichel, 2011; Ritchie, 2004). Such initiatives not only have a direct impact on tourist arrivals but are also able to highlight positive events as a way to influence favorable media coverage.

(5) The media's news coverage undermines (or strengthens) the marketing efforts of hotels to attract tourism flows. Media coverage is important because negative or positive news and information have an effect on the perception of potential tourists and travel demand into the area. The literature shows that alarmist tones and sensationalist reporting of the media can generate a hysterical overreaction out of proportion to the real degree of risk or insecurity (see Lynch, 2004; Villanueva-Rivas, 2011). Thus, higher tourism flow volumes are induced not just by the communication mix of hotels and the promotion efforts of quasi-governmental organizations, but also depend largely on the media's coverage of news. 
IHR

36,1

146

\section{Conclusions}

\section{Summary}

In the tourism and hospitality literature, the use and enhancements of hotels' product-related features have been studied in various risk and insecurity contexts (e.g. terrorism, political conflicts), while overlooking the role of the other crucial marketing mix activities (distribution, pricing and promotion) and the factors that determine their implementation. This neglect constitutes a lacuna in the extant body of knowledge in the field, since the full marketing mix tools, altogether, comprise capabilities through which firms create and deliver value to remain competitive in the marketplace (Hunt, 2010; Kumar, 2018; Vorhies and Morgan, 2005). Therefore, the purpose of this research was to investigate the specific marketing mix actions and influencing factors in businesses in the hotel sector in the midst of increased insecurity and violence derived from organized crime presence, a growing problem not only in America, but also around the world (Drug Enforcement Agency, 2017; United Nations Office on Drugs and Crime, 2010).

The first research question was what are the marketing mix tactics commonly implemented by hotels in the context of risk and insecurity in a tourism region? A listing of marketing mix activities was generated (Table 2) based on interviews to hotel managers in the bi-national border region of McAllen (United States) and Reynosa (Mexico). Accordingly, most hotels responded to the crime-related insecurity crisis by making adjustments to the elements of pricing, particularly through reduction of rates and discounts. In addition, a large proportion of the hotels relied on communication activities to cope with falling room demand, especially through greater advertising and more emphasis on personal sales efforts. It was also found that product-service enhancements (a topic that has gained considerable attention of researchers examining hotels' responses in risk- and safety-crisis contexts) and distribution channels tactics were not implemented in the same extent as the other marketing mix activities. Such results allowed to respond the second research question: What factors influence the implementation of such marketing mix tactics by the firms? The findings show how the decisions to deploy marketing mix activities are jointly determined by variables within and outside the firm (Bowie and Buttle, 2011; Shipp and Lamb, 1996). This is illustrated in the resulting framework (Figure 2) that depicts internal factors (market segment diversification, type of ownership, magnitude of investments) and external factors (tourism promotion organizations, media coverage, tourist flow volume) that influence marketing mix implementation during insecurity crises in the tourism industry.

\section{Theoretical and managerial implications}

The study allows to contextualize factors found in strategic marketing management models. For example, the research supports the role of the firm's internal resources (e.g. comparative advantages, market position, financial assets) and external environment (e.g. competition, institutions, public policy) outlined in the resource-advantage theory (Hunt, 2010) and their importance to leverage available capabilities, target specific market segments and develop the 'marketing mixes' in heterogeneous forms. In this regard, identifying and assessing the factors in the proposed framework (Figure 2), which may ease or inhibit the deployment of resources to implement various marketing mix activities, contributes to better understand the formulation of marketing strategies and decisions. From the situational crisis perspective, it seems that the marketing mix responses implemented by the hotels in the study were prompted by a contingency-based management approach (Kulkarni, 2017). According to contingency theory, there is no "one best way" to structure and manage organizations because such decisions are contingent upon the environment, so the organization's adaptation and survival (particularly during times of conflict, crises, or threats) can be achieved in more than one single way. Considering that businesses operate under high levels 
of uncertainty, complexity and competition, management needs to achieve a "good fit" between internal systems/resources and the external environment in order to be successful (Kulkarni, 2017). The contingency-based view has been employed to explain marketing decisions (Williams et al., 2017), including those in the hotel industry (Fernández-Robin et al., 2019) and in crisis responses in contexts such as political instability (Masa'deh et al., 2018; Sawalha et al., 2013) or the recent coronavirus disease 2019 (COVID-19) pandemic outbreak (Lai and Wong, 2020).

This work also studied the hotel industry at tourism destinations stricken by insecurity and violence derived from cartel-related organized crime, an understudied context in the literature. As outlined in Ritchie and Jiang's (2019) systematic review on the crisis management literature, multiple cases (risk types and/or destinations) are still lacking in the current body of knowledge in tourism and hospitality. Additionally, the research extends the knowledge and understanding of hotels' marketing mix practices in reaction to risk and insecurity situations, adding a new framework to the existing hospitality crisis response literature which had incorporated marketing concepts in an abstract manner, but without specifying the full marketing mix tactics implemented by hotels (Wang and Ritchie, 2010). Thus, the development of broader, more general models of crisis management in the hotel industry should take into consideration the particular characteristics of firms and their environment in terms of their ability to deploy marketing mix activities when operating in crime-ridden destinations, which might also be applicable to other risk and insecurity settings (i.e. political instability, terrorism). This can contribute to better understand and explain the resilience of hospitality business in times of crisis (Dahles and Susilowati, 2015; Jiang et al., 2019; Ritchie and Jiang, 2019), which to some extent appears to be related to the internal and external factors outlined in the proposed framework.

From a managerial standpoint, study results suggest that hotel practitioners need to assess their degree of market segment diversification and increase it to the extent possible as a way to become less vulnerable to sudden shifts in demand. According to Bronner and de Hoog (2014), understanding the occurrence of crises and their impact upon travelers can help in the development of adequate marketing strategies (for example, avoiding overreliance on price discounting and focusing instead on non-economizers, considered less price-sensitive target segments). Additionally, when budgets are limited but improvements to productsservices are deemed necessary, a creative approach is to envisage product modifications that do not represent prohibitively expensive investments but have the greatest impact in terms of customer responsiveness. For such strategies, determinations should not be made without the necessary data and insights derived from research, as often occurs in crisis situations when urgent actions are prompted by intuition (Engemann, 2018). Also, hoteliers should take into account the implications that different types of ownership and brand affiliations have on the possibility to implement adjustments in communication activities and attempt to open new distribution channels that augment guest flows. Those decisions are often dependent on the hotel's size and category, which are positively associated to greater crisis planning and response (Ritchie et al., 2011).

The high intensity of pricing and communication activities implemented by hotels in the study draws the attention to what appears to be an inertial approach taken by the firms under study (Gilbert, 2005). For instance, an overreliance on price discounting goes in opposite direction to empirical research results recommending practitioners to avoid hotel rate reductions as a reactive tactic in turbulent, uncertain times (see Enz et al., 2009). Similarly, too much emphasis on advertising and promotional efforts can be ineffective if other components of the marketing mix (e.g. product/service, distribution) are not properly deployed. According to Bowie and Buttle (2011), managers often think that communication campaigns compensate for deficiencies in other elements of the marketing mix, but if the hotel's integral offer does not satisfy customers in a holistic way, then investing in marketing communications can be a 
IHR

36,1

148

waste of resources. Thus, developing products and services oriented to value-creation (Shaw et al., 2011) and distribution channels convenient for customers (Rosenbloom, 2013) should be also prioritized in lodging firms' strategies.

Based on the asymmetric composition of marketing mix practices implemented by the hotels that participated in this investigation (mostly price discounts and communications tactics, limited product-development and distribution channels tactics), it seems that the research-based body of knowledge and insights generated from academic literature does not flow well into the industry. To some extent, this case study reflects the academic-practitioner divide that has long represented a challenge in the marketing research community (see Lilien, 2011), which also extends to the hospitality field (see Vong, 2017). Therefore, it is necessary for university-level tourism and hospitality programs to make an effort not only to better communicate and disseminate the research of their faculty members but also to more directly participate in industry-academia collaborations (Griffin, 2021). As stressed by Ritchie and Jiang (2019), research on tourism risk and crisis management must be increasingly oriented to evaluate, foster and promote greater crisis knowledge among practitioners in the industry.

With respect to the role of external factors influencing marketing mix implementation, hotel managers should proactively work in conjunction with tourism organizations and official agencies by launching coordinated programs to promote travel and visitation, support large group events and conventions and use public relation campaigns that trigger positive news coverage to counteract negative news. However, narcoviolence and lawlessness are manifestations of complex problems and phenomena which require largescale, joint efforts by government, businesses and society as a whole to address and solve. The harmful effects of drug-cartels' activities in a region/country are not to be ultimately solved by individual hospitality firms, which are at the bottom of the policymaking hierarchy in crisis situations (Kuo et al., 2017). In this regard, the lodging industry, tourism associations and chambers of commerce should coordinate and support long-term initiatives launched by authorities and other community stakeholders to contribute to improve the safety and security at tourism destinations.

\section{Limitations and future research}

In further investigations, quantitative approaches may be implemented to research the resulting framework advanced in this study. The focus on just one geographic region also calls for caution in inferring generalizations. As noted by Chakravarti and Crabbe (2019), the goal of case studies is to understand a phenomenon in the focal case context, rather than extrapolating directly to other instances or settings. Moreover, the list of marketing mix tactics identified through a qualitative inquiry could serve as the basis for future instrument and scale development (Bryman, 2006) to research crisis management responses in the hospitality industry. It is suggested that other scholars study the effectiveness of different marketing mix tactics by using objective hotel performance metrics and also in terms of attracting additional segments of travelers in the context of a crisis in a tourism destination. Finally, future investigations could employ other categorizations of the marketing mix, such as the 7 P's including "people", "processes" and "physical evidence" (Zeithaml et al., 2017), or the 8 P's including the "physical location" (Bowie and Buttle, 2011) that are also found in the services and hospitality literature.

\section{References}

Aaltio, I. and Heilmann, P. (2010), “Case study as a methodological approach”, in Mills, A.J., Durepos, G. and Wiebe, E. (Eds), Encyclopedia of Case Study Research, SAGE, Thousand Oaks, pp. 67-78.

Aassaf, A.G. and Josiassen, A. (2012), "Identifying and ranking the determinants of tourism performance: a global investigation”, Journal of Travel Research, Vol. 51 No. 4, pp. 388-399. 
Alonso-Almeida, M.D.M., Bremser, K. and Llach, J. (2015), "Proactive and reactive strategies deployed by restaurants in times of crisis: effects on capabilities, organization and competitive advantage", International Journal of Contemporary Hospitality Management, Vol. 27 No. 7, pp. 1641-1661.

Altinay, L. and Paraskevas, A. (2008), Planning Research in Hospitality and Tourism, ButterworthHeinemann, Oxford.

Ardley, B. (2008), "Articles of faith and mystic matrices. Marketing textbooks and the misrepresentation of reality", Qualitative Market Research: An International Journal, Vol. 11 No. 4, pp. 372-385.

Bar-On, R.R. (1996), "Measuring the effects on tourism of violence and of promotion following violent acts", in Pizam, A. and Mansfeld, J. (Eds), Tourism, Crime and International Security Issues, Wiley, West Sussex, pp. 159-174.

Baruca, A. and Zolfagharian, M. (2013), "Cross-border shopping: Mexican shoppers in the US and American shoppers in Mexico", International Journal of Consumer Studies, Vol. 37 No. 4, pp. 360-366.

Blackman, D. and Ritchie, B.W. (2007), "Tourism crisis management and organizational learning: the role of reflection in developing effective DMO crisis strategies", Journal of Travel and Tourism Marketing, Vol. 23, pp. 45-57.

Blut, M., Teller, C. and Floh, A. (2018), "Testing retail marketing-mix effects on patronage: a metaanalysis", Journal of Retailing, Vol. 94 No. 2, pp. 113-135.

Bojanic, D. (2008), "Hospitality marketing mix and service marketing principles", in Oh, H. and Pizam, A. (Ed.s), Handbook of Hospitality Marketing Management, Butterworth-Heinemann, Oxford, pp. 59-84.

Borden, N.H. (1964), "The concept of the marketing mix", Journal of Advertising Research June, pp. 2-7.

Bowie, D. and Buttle, F. (2011), Hospitality Marketing: Principles and Practice, 2nd ed., ButterworthHeinemann, Oxford.

Bronner, F. and de Hoog, R. (2014), "Vacationers and the economic 'double dip' in Europe”, Tourism Management, Vol. 40, pp. 330-337.

Brunt, P., Mawby, R. and Hambly, Z. (2000), "Tourist victimization and the fear of crime on holiday", Tourism Management, Vol. 21, pp. 417-424.

Bryman, A. (2006), "Integrating quantitative and qualitative research: how is it done?", Qualitative Research, Vol. 6 No. 1, pp. 97-113.

Bussey, J. (2012), “Amid murders, Mexico quietly thrives”, The Wall Street Journal February 10, p. B1.

Caber, M., González-Rodríguez, M.R., Albayrak, T. and Simonetti, B. (2020), "Does perceived risk really matter in travel behaviour?", Journal of Vacation Marketing, Vol. 26 No. 3, pp. 334-353.

Campiranon, K. and Scott, N. (2014), "Critical success factors for crisis recovery management: a case study of Phuket hotels", Journal of Travel and Tourism Marketing, Vol. 31 No. 3, pp. 313-326.

Carlsen, J.C. and Liburd, J.J. (2007), "Developing a research agenda for tourism crisis management, market recovery and communications", Journal of Travel and Tourism Marketing, Vol. 23, pp. 265-276.

Cavlek, N. (2002), "Tour operators and destination safety", Annals of Tourism Research, Vol. 29, pp. 478-496.

Chakravarti, D. and Crabbe, R. (2019), "Qualitative research for consumer psychology", in Kardes, F.R., Herr, P.M. and Schwarz, N. (Eds), Handbook of Research Methods in Consumer Psychology, Routhledge, New York, NY, pp. 61-92.

Cizmar, S. and Weber, S. (2000), "Marketing effectiveness of the hotel industry in Croatia", International Journal of Hospitality Management, Vol. 19, pp. 227-240.

Claver-Cortés, E., Pereira-Moliner, J. and Andreu-Guerrero, R. (2006), "Impacto de las instalaciones sobre el desempeño del sector hotelero español”, Revista de Análisis Turístico No. 2, pp. 6-20. 
IHR

36,1

Constantinides, E. (2006), “The marketing mix revisited: towards the 21st century marketing”, Journal of Marketing Management, Vol. 22, pp. 407-438.

Correa-Cabrera, G. (2013), "Security, migration, and the economy in the Texas-tamaulipas border region: the 'real' effects of Mexico's drug war", Politics and Policy, Vol. 41 No. 1, pp. 65-82.

Cruz-Milán, O. (2017), "Mexico", in Lowry, L.L. (Ed.), The SAGE International Encyclopedia of Travel and Tourism, SAGE, Thousand Oaks, pp. 824-828.

Dahles, H. and Susilowati, T.P. (2015), "Business resilience in times of growth and crisis", Annals of Tourism Research, Vol. 51, pp. 34-50.

Datta, H., Ailawadi, K.L. and van Heerde, H.J. (2017), "How well does consumer-based brand equity align with sales-based brand equity and marketing-mix response?", Journal of Marketing, Vol. 81 No. 3, pp. 1-20.

Daymon, C. and Holloway, I. (2011), Qualitative Research Methods in Public Relations and Marketing Communications, 2nd ed., Routledge, New York, NY.

de la Torre, M.I. and Navarrete Escobedo, D. (2018), “Turismo y narcotráfico en México”, Estudios y Perspectivas en Turismo, Vol. 27 No. 4, pp. 867-882.

Department of State (2011), "Warden message to inform U.S. citizens about the potential dangers of inter-city bus travel in Tamaulipas April 8, 2011", available at: http://matamoros.usconsulate. gov/wm04082011en.html (accessed 15 November 2011).

Department of State (2018), "Mexico travel advisory", available at: https://travel.state.gov/content/ travel/en/traveladvisories/traveladvisories/mexico-travel-advisory.html (accessed 5 May 2018).

Dolnicar, S., Yanamandram, V. and Cliff, K. (2012), "The contribution of vacations to quality of life", Annals of Tourism Research, Vol. 39 No. 1, pp. 59-83.

Drug Enforcement Agency (2017), Colombian Cocaine Production Expansion Contributes to Rise in Supply in the United States, DEA Intelligence Brief, (DEA-DCT-DIB-014-17), available at: https:// www.dea.gov/sites/default/files/2018-07/DIB-014-17\%20Colombian \%20Cocaine \%20Production \%20Expansion_1.pdf (accessed 16 December 2020).

Engemann, K.J. (2018), "Developments in risk security", in Engemann, K.J. (Ed.), The Routledge Companion to Risk, Crisis and Security in Business, Routledge, New York, NY.

Enz, C.A. (2009), "The physical safety and security features of US hotels", Cornell Hospitality Quarterly, Vol. 50 No. 4, pp. 553-560.

Enz, C.A. and Taylor, M.S. (2002), "The safety and security of US hotels-a post-September-11 report", Cornell Hotel and Restaurant Administration Quarterly, Vol. 43 No. 5, pp. 119-136.

Enz, C.A., Canina, L. and Lomanno, M. (2009), "Competitive pricing decisions in uncertain times", Cornell Hospitality Quarterly, Vol. 50 No. 3, pp. 325-341.

Fakis, A., Hilliam, R., Stoneley, H. and Townend, M. (2014), "Quantitative analysis of qualitative information from interviews: a systematic literature review", Journal of Mixed Methods Research, Vol. 8 No. 2, pp. 139-161.

Faulkner, B. (2001), “Towards a framework for tourism disaster management”, Tourism Management, Vol. 22, pp. 135-147.

Fawzy, A. (2010), "Business travelers' accommodation selection: a comparative study of two international hotels in Cairo", International Journal of Hospitality and Tourism Administration, Vol. 11, pp. 138-156.

Feickert, J., Verma, R., Plaschka, G. and Dev, C.S. (2006), "Safeguarding your customers: the guest's view of hotel security", Cornell Hotel and Restaurant Administration Quarterly, Vol. 47 No. 3, pp. 224-244.

Fernández-Robin, C., Celemín-Pedroche, M.S., Santander-Astorga, P. and Alonso-Almeida, M.M. (2019), "Green practices in hospitality: a contingency approach", Sustainability, Vol. 11 No. 13, p. 3737. 
Ferreyra, G. (2015), "Drugs and drug control in Mexico", in Kalunta-Crumpton, A. (Ed.), Pan-African Issues in Drus and Drug Control, Routledge, New York, NY, pp. 265-284.

Fuchs, G. and Reichel, A. (2006), "Tourist destination risk perception: the case of Israel", Journal of Hospitality and Leisure Marketing, Vol. 14, pp. 83-108.

Fuchs, G. and Reichel, A. (2011), "An exploratory inquiry into destination risk perceptions and risk reduction strategies of first time vs. repeat visitors to a highly volatile destination", Tourism Management, Vol. 32, pp. 266-276.

Fullerton, T.M. and Walke, A.G. (2014), "Homicides, exchange rates, and northern border retail activity in Mexico", The Annals of Regional Science, Vol. 53, pp. 631-647.

Gilbert, C.G. (2005), "Unbundling the structure of inertia: resource versus routine rigidity", The Academy of Management Journal, Vol. 48 No. 5, pp. 741-763.

Goulding, C. (1998), "Grounded theory: the missing methodology on the interpretivist agenda", Qualitative Market Research: An International Journal, Vol. 1, pp. 50-57.

Green, C.G., Bartholomew, P. and Murrmann, S. (2003), "New York restaurant industry: strategic responses to September 11, 2001”, Journal of Travel and Tourism Marketing, Vol. 12, pp. pp63-79.

Griffin, W.C. (2021), "Perceptions of hospitality industry professionals and hospitality faculty on industry-academia collaborations", Journal of Hospitality and Tourism Education, Ahead of print, doi: 10.1080/10963758.2020.1791137.

Ho, T., Zhao, J. and Dooley, B. (2017), "Hotel crimes: an unexplored victimization in the hospitality industry", Security Journal, Vol. 30 No. 4, pp. 1097-1111.

Huang, Y.C., Tseng, Y.P. and Petrick, J.F. (2007), "Crisis management planning to restore tourism after disasters: a case study from Taiwan", Journal of Travel and Tourism Marketing, Vol. 23, pp. 203-221.

Hunt, S.D. (2010), Marketing Theory: Foundations, Controversy, Strategy, Resource-Advantage Theory, M.E Sharpe, Armonk.

Israeli, A.A., Mohsin, A. and Kumar, B. (2011), "Hospitality crisis management practices: the case of Indian luxury hotels", International Journal of Hospitality Management, Vol. 30, pp. 367-374.

Jiang, Y., Ritchie, B.W. and Benckendorff, P. (2019), "Bibliometric visualisation: an application in tourism crisis and disaster management research", Current Issues in Tourism, Vol. 22 No. 16, pp. 1925-1957.

Johnson Tew, P., Lu, Z., Tolomiczenko, G. and Gellatly, J. (2008), "SARS: lessons in strategic planning for hoteliers and destination marketers", International Journal of Contemporary Hospitality Management, Vol. 20 No. 3, pp. 332-346.

Karl, M., Muskat, B. and Ritchie, B.W. (2020), "Which travel risks are more salient for destination choice? an examination of the tourist's decision-making process", Journal of Destination Marketing and Management, Vol. 18, December, Article 100487, doi: 10.1016/j.jdmm.2020. 100487.

Kerlinger, F.N. and Lee, H.B. (2000), Foundations of Behavioral Research, 4th ed., Cengage Learning, Belmont.

Kim, M.-S. and Kim, J. (2018), "Linking marketing mix elements to passion-driven behavior toward a brand", International Journal of Contemporary Hospitality Management, Vol. 30 No. 10, pp. 3040-3058.

Kim, M., Roehl, W. and Lee, S.K. (2019), "Effect of hotels' price discounts on performance recovery after a crisis", International Journal of Hospitality Management, Vol. 83, pp. 74-82.

Kock, F., Assaf, A.G. and Tsionas, M.G. (2020), "Developing courageous research ideas", Journal of Travel Research, Vol. 59 No. 6, pp. 1140-1146.

Kotler, P. and Keller, K.L. (2016), A Framework for Marketing Management, 6th ed., Pearson, Boston. 
IHR

36,1

Kotler, P., Bowen, J.T., Makens, J.C. and Baloglu, S. (2016), Marketing for Hospitality and Tourism, 7th ed., Pearson, Boston.

Kozak, M., Crotts, J.C. and Law, R. (2007), "The impact of the perception of risk on international travellers", International Journal of Tourism Research, Vol. 9 No. 4, pp. 233-242.

Kulkarni, V. (2017), "Contingency theory", in Scott, C.R. and Lewis, L. (Eds), The International Encyclopedia of Organizational Communication, John Wiley and Sons.

Kumar, V. (2018), "A theory of customer valuation: concepts, metrics, strategy, and implementation", Journal of Marketing, Vol. 82, pp. 1-19.

Kumar, V., Fan, J., Gulati, R. and Venkat, P. (2009), "Marketing-mix recommendations to manage value growth at P\&G Asia-Pacific", Marketing Science, Vol. 28 No. 4, pp. 645-655.

Kuo, C.M., Liou, Y.C. and Boger, E.P. (2017), "The Impact of crisis events and recovery strategies on international hotels", The Consortium Journal of Hospitality and Tourism, Vol. 21 No. 1, pp. 49-63.

Kwok, L., Tang, Y. and Yu, B. (2020), "The 7 Ps marketing mix of home-sharing services: mining travelers' online reviews on Airbnb", International Journal of Hospitality Management, Vol. 90, September, Article 102616, doi: 10.1016/j.ijhm.2020.102616.

Ladik, D.M. and Stewart, D.W. (2008), "The contribution continuum", Journal of the Academy of Marketing Science, Vol. 36 No. 2, pp. 157-165.

Lai, I.K.W. and Wong, J.W.C. (2020), "Comparing crisis management practices in the hotel industry between initial and pandemic stages of COVID-19", International Journal of Contemporary Hospitality Management, Vol. 32 No. 10, pp. 3135-3156.

LeCompte, M.D. and Schensul, J.J. (1999), Analyzing and Interpreting Ethnographic Data, AltaMira Press, Lanham.

Leung, X.Y., Yang, Y. and Dubin, E.A. (2018), "What are guests scared of? Crime-related hotel experiences and fear of crime”, Journal of Travel and Tourism Marketing, Vol. 35 No. 8, pp. 1071-1086.

Lewis, R.C. and Chambers, R.E. (2000), Marketing Leadership in Hospitality, 3rd ed., Wiley, New York, NY.

Lilien, G.L. (2011), "Bridging the academic-practitioner divide in marketing decision models", Journal of Marketing, Vol. 75 No. 4, pp. 196-210.

Loo, P.T. and Leung, R. (2018), "A service failure framework of hotels in Taiwan: adaptation of 7Ps marketing mix elements", Journal of Vacation Marketing, Vol. 24 No. 1, pp. 79-100.

Lynch, M. (2004), Weathering the Storm: A Crisis Management Guide for the Tourism Business, Matador, Leicester.

Mair, J., Ritchie, B.W. and Walters, G. (2016), “Towards a research agenda for post-disaster and postcrisis recovery strategies for tourist destinations: a narrative review", Current Issues in Tourism, Vol. 19 No. 1, pp. 1-26.

Marshall, G.W. and Johnston, M.W. (2019), Marketing Management, 3rd ed., McGraw-Hill, New York, NY.

Masa'deh, R., Alananzeh, O., Tarhini, A. and Algudah, O. (2018), "The effect of promotional mix on hotel performance during the political crisis in the Middle East", Journal of Hospitality and Tourism Technology, Vol. 9 No. 1, pp. 33-49.

Maxwell, J.A. (2010), "Using numbers in qualitative research", Qualitative Inquiry, Vol. 16 No. 6, pp. $475-482$.

McCracken, G. (1988), The Long Interview, Sage, Newbury Park.

McElroy, J.L. (2006), "The growth of the Caribbean narcoeconomy: implications for tourism", in Mansfeld, J. and Pizam, A. (Eds), Tourism, Security and Safety: From Theory to Practice, Elsevier, Oxford, pp. 87-104. 
McGehee, N.G. (2012), "Interview techniques", in Dwyer, L., Gill, A. and Seetaram, N. (Eds), Handbook of Research Methods in Tourism: Quantitative and Qualitative Approaches, Edward Elgar, Cheltenham, pp. 365-376.

Meidan, A. (1984), “The marketing of tourism”, The Service Industries Journal, Vol. 4 No. 3, pp. 166-186.

Mintz, O. and Currim, I.S. (2015), "When does metric use matter less? How firm and managerial characteristics moderate the relationship between metric use and marketing mix performance", European Journal of Marketing, Vol. 49 Nos 11/12, pp. 1809-1856.

Monterrubio, C., Andriotis, K. and Stylidis, D. (2020), Tourism Planning and Development in Latin America, CABI, Oxfordshire.

Nivin, S. (2013), The Spending Patterns and Economic Impacts of Mexican Nationals in a TwentyCounty Region of South and Central Texas, Strategic Alliance for Business and Economic Research (SABÉR) Institute. St. Mary's University and San Antonio Hispanic Chamber of Commerce, San Antonio, TX.

Paraskevas, A. and Altinay, L. (2013), "Signal detection as the first line of defence in tourism crisis management", Tourism Management, Vol. 34, pp. 158-171.

Pennington-Gray, L. (2018), "Reflections to move forward: where destination crisis management research needs to go", Tourism Management Perspectives, Vol. 25, pp. 136-139.

Pennington-Gray, L., Thapa, B., Kaplanidou, K., Cahyanto, I. and McLaughlin, E. (2011), "Crisis planning and preparedness in the United States tourism industry", Cornell Hospitality Quarterly, Vol. 52 No. 3, pp. 312-320.

Pizam, A. and Mansfeld, J. (2006), “Toward a theory of tourism security”, in Mansfeld, J. and Pizam, A. (Eds), Tourism, Security and Safety: From Theory to Practice, Elsevier, Oxford, pp. 1-27.

Plog, S.C. (2006), "A commentary on effective responses to tourism disasters", Cornell Hotel and Restaurant Administration Quarterly, Vol. 47 No. 4, pp. 405-410.

Radišić, B.B., Perišić, M. and Berečić, J. (2010), "Marketing in selling the hotel product", Tourism and Hospitality Management Supplement, pp. 771-782.

Ritchie, B.W. (2004), "Chaos, crises and disasters: a strategic approach to crisis management in the tourism industry", Tourism Management, Vol. 25, pp. 669-683.

Ritchie, B.W. and Jiang, Y. (2019), "A review of research on tourism risk, crisis and disaster management: launching the annals of tourism research curated collection on tourism risk, crisis and disaster management", Annals of Tourism Research, Vol. 79, November, Article 102812, doi: 10.1016/j.annals.2019.102812.

Ritchie, B.W., Bentley, G., Koruth, T. and Wang, J. (2011), "Proactive crisis planning: lessons for the accommodation industry", Scandinavian Journal of Hospitality and Tourism, Vol. 11, pp. 367-386.

Rittichainuwat, B.N. (2013), “Tourists' perceived risks toward overt safety measures”, Journal of Hospitality and Tourism Research, Vol. 3 No. 2, pp. 199-216.

Rittichainuwat, B.N. and Chakraborty, G. (2012), "Perceptions of importance and what safety is enough", Journal of Business Research, Vol. 65 No. 1, pp. 42-50.

Rosenbloom, B. (2013), "Functions and institutions: the roots and the future of marketing channels", Journal of Marketing Channels, Vol. 20 Nos 3/4, pp. 191-203.

Rubin, H.J. and Rubin, I.S. (2005), Qualitative Interviewing: The Art of Hearing Data, 2nd ed., Sage, Thousand Oaks.

Rushmore, S. (2002), Hotel Investments Handbook, HVS International, Mineola.

Sánchez-Munguía, V. (2011), "The current Mexican government's fight against crime in the U.S.Mexican border", Frontera Norte, Vol. 23, pp. 97-130. 
IHR

36,1

Salman, D., Tawfik, Y., Samy, M. and Artal-Tur, A. (2017), "A new marketing mix model to rescue the hospitality industry: evidence from Egypt after the Arab Spring”, Future Business Journal, Vol. 3 No. 1, pp. 47-69.

Sandoval-Hernández, E. (2008), "Memoria y conformación histórica de un espacio social para el consumo entre el noreste de México y el sur de Texas", Relaciones, Vol. 29, pp. 235-273.

Santana, G. (2003), "Crisis management and tourism: beyond the rhetoric", Journal of Travel and Tourism Marketing, Vol. 15, pp. 299-321.

Sawalha, I.H.S., Jraisat, L.E. and Al-Qudah, K.A.M. (2013), "Crisis and disaster management in Jordanian hotels: practices and cultural considerations", Disaster Prevention and Management: An International Journal, Vol. 22 No. 3, pp. 210-228.

Secretaría de Seguridad y Protección Ciudadana (2020), Tasas por cada 100 mil habitantes 19972017, Secretariado Ejecutivo del Sistema Nacional de Seguridad Pública, SSPC, México.

Secretaría de Turismo (2018), Compendio Estadístico del Turismo en México 2017, SECTUR, México.

Shaw, E.H. (2012), "Marketing strategy: from the origin of the concept to the development of a conceptual framework", Journal of Historical Research in Marketing, Vol. 4 No. 1, pp. 30-55.

Shaw, G., Bailey, A. and Williams, A. (2011), "Aspects of service-dominant logic and its implications for tourism management: examples from the hotel industry", Tourism Management, Vol. 32 No. 2, pp. 207-214.

Shelley, L.I. (1995), "Organized crime: an imminent threat to the nation-state?”, Journal of International Affairs, Vol. 48 No. 2, pp. 463-489.

Shipp, S.H. and Lamb, C.W. (1996), "The effect of selected environmental variables of the marketing mix/SBU performance relationship", Journal of Strategic Marketing, Vol. 4, pp. 143-162.

Simpson, P.M. and Siguaw, J.A. (2008), "Perceived travel risks: the traveller perspective and manageability", International Journal of Tourism Research, Vol. 10, pp. 315-327.

Simpson, P., Cruz-Milán, O. and Gressel, J. (2014), "Perceived crime and violence: effects on winter migrants", Journal of Travel Research, Vol. 53 No. 5, pp. 597-609.

Sönmez, S.F., Backman, S.J. and Allen, L.R. (1994), Managing Tourism Crises: A Guidebook, Department of Parks, Recreation, and Tourism Management, Clemson University, Clemson, SC.

Sönmez, S.F., Apostolopoulos, Y. and Tarlow, P. (1999), "Tourism in crisis: managing the effects of terrorism”, Journal of Travel Research, Vol. 38 No. 1, pp. 13-18.

Speakman, M. and Sharpley, R. (2012), "A chaos theory perspective on destination crisis management: evidence from Mexico", Journal of Destination Marketing and Management, Vol. 1 Nos 1-2, pp. 67-77.

Stutts, A.T. and Wortman, J.F. (2006), Hotel and Lodging Management: An Introduction, 2nd ed., Wiley, Hoboken.

Tarlow, P.E. (2014), Tourism Security : Strategies for Effectively Managing Travel Risk and Safety, Butterworth-Heinemann, Oxford.

Taylor, M.S. and Enz, K. (2002), "GMs' responses to the events of September 11, 2001", Cornell Hotel and Restaurant Administration Quarterly, Vol. 43 No. 1, pp. 7-20.

Tilson, D.J. and Stacks, D.W. (1997), "To know us is to love us: the public relations campaign to sell a 'business-tourist-friendly' Miami”, Public Relations Review, Vol. 23, pp. 95-115.

Tsiotsou, R.H. and Goldsmith, R.E. (2012), Strategic Marketing in Tourism Services, Emerald, Bingley.

United Nations Office on Drugs and Crime (2010), "The globalization of crime: a transnational organized crime threat assessment", available at: https://www.unodc.org/documents/data-andanalysis/tocta/TOCTA_Report_2010_low_res.pdf (accessed 16 December 2020).

Van Waterschoot, W. and Van den Bulte, C. (1992), "The 4P classification of the marketing mix revisited", Journal of Marketing, Vol. 56 No. 4, pp. 83-93. 
Villanueva-Rivas, C. (2011), “The rise and fall of Mexico's international image: stereotypical identities, media strategies and diplomacy dilemmas", Place Branding and Public Diplomacy, Vol. 7 No. 1, pp. 23-31.

Vong, F. (2017), "Relevance of academic research to hospitality practitioners", Journal of Hospitality and Tourism Education, Vol. 29 No. 3, pp. 116-128.

Vorhies, D.W. and Morgan, N.A. (2005), "Benchmarking marketing capabilities for sustainable competitive advantage", Journal of Marketing, Vol. 69 No. 1, pp. 80-94.

Wang, J. and Ritchie, B.W. (2010), "A theoretical model for strategic crisis planning: factors influencing crisis planning in the hotel industry", International Journal of Tourism Policy, Vol. 3 , pp. 297-317.

Whetten, D. (1989), "What constitutes a theoretical contribution?", Academy of Management Review, Vol. 14 No. 4, pp. 490-495.

Williams, P., Ashill, N. and Naumann, E. (2017), "Toward a contingency theory of CRM adoption", Journal of Strategic Marketing, Vol. 25 Nos 5-6, pp. 454-474.

Xiao, H. (2010), "Case study research in tourism", in Mills, A.J., Durepos, G. and Wiebe, E. (Eds), Encyclopedia of Case Study Research, SAGE, Thousand Oaks, pp. 122-125.

Zárate-Ruiz, A. and López-León, A. (2016), "Estudio sobre la violencia en Tamaulipas: diagnóstico y acciones de respuesta", Proceedings of the Seminario Sobre Violencia y Paz. Conferencia Mexicana sobre Violencia y Paz desde lo Local, El Colegio de México, Mexico City, pp. 1-57.

Zeithaml, V.A., Bitner, M.J. and Gremler, D.D. (2017), Services Marketing: Integrating Customer Focus across the Firm, 7th ed., McGraw-Hill, New York, NY.

Zhao, J. and Ho, T. (2006), "Are foreign visitors more likely victimized in hotels? Policy implications", Security Journal, Vol. 19 No. 1, pp. 33-44.

\section{Corresponding author}

Oliver Cruz-Milán can be contacted at: Oliver.CruzMilan@tamucc.edu

For instructions on how to order reprints of this article, please visit our website:

www.emeraldgrouppublishing.com/licensing/reprints.htm

Or contact us for further details: permissions@emeraldinsight.com 